\title{
Conceptualising Resilience in the Context of Transitional Justice
}

\author{
Wendy Lambourne
}

This chapter reflects on the implications of resilience thinking for transitional justice as a transformative process that contributes to adaptive peacebuilding. Recognising that resilience is highly relevant to a number of core transitional justice goals, including the re-establishment of the rule of law, peace and reconciliation, it discusses how the concept creates a space for new thinking about transitional justice. In so doing, it explores the extent to which transitional justice processes affect and engage with multiple interacting systems in ways that can foster resilience and adaptive capacity across these systems and the relationships that underpin them.

The chapter examines how each of the primary state-based mechanisms of transitional justice - namely, criminal trials, truth commissions and reparations - might contribute to systemic societal resilience, notwithstanding their limitations, and discusses their potential for healing divisions and building relationships to support resilient social structures. It also considers how more community-driven facilitated justice processes, including traditional customary practices and psychosocial programmes, can expand the basis for building resilient communities and systems.

As part of this analysis, the chapter provides a critical appraisal of the overall approach to transitional justice that has dominated the field, considering transformative justice as an alternative perspective that challenges a politicolegal, state-based, backward-looking retributive framework. It argues that resilience thinking supports a greater focus on psychosocial, communitybased, forward-looking restorative approaches to transitional justice, consistent with the transformative turn in the field (Gready and Robins, 2014; Lambourne, 2014a). This is demonstrated by exploring different understandings of justice, how they are pursued in the context of transitional justice and what they mean for building resilient societies after mass violence and human rights violations. The chapter concludes by reflecting on the potential for 
a transformative approach to transitional justice consistent with building resilience to support adaptive peacebuilding in practice.

\section{UNDERSTANDING TRANSITIONAL JUSTICE AND TYPES OF JUSTICE}

Transitional justice can be defined as a process intended to provide justice for mass human rights violations committed in the context of war or a past autocratic regime. The idea of 'transition' is key - from a past where human rights were violated with impunity to a future characterised by democracy and the rule of law, which, in turn, is assumed to lead to the protection of human rights (International Center for Transitional Justice, 2001). In the context of post-war transitions, the goals of transitional justice are more explicitly linked to peacebuilding, going beyond democracy and the rule of law to the pursuit of truth, reconciliation and institutional reform (United Nations [UN], 2004).

However, in some cases, transitional justice processes are also implemented in periods of non-transition, where justice is sought for ongoing mass human rights violations or where the regime that committed the violations in the past is still in place. Winter (2014), moreover, argues for a political theory of transitional justice that applies to the context of authorised wrongdoings by established democracies (such as those perpetrated against Japanese Americans during World War II). Transitional justice thinking has therefore been applied to situations of ongoing colonial and post-colonial oppression, including the treatment of Indigenous peoples by settler societies, such as in Canada where a Truth and Reconciliation Commission (TRC) on Indian residential schools was established in 2008 (Nagy, 2013; Niezen, 2013).

What transitional justice might look like thus varies across different settings. There might be a focus on retributive justice to punish those accused of committing mass atrocities as a means of ensuring non-repetition, as highlighted by the example of the International Criminal Tribunal for the former Yugoslavia (ICTY). Alternatively, the main priority might be restorative justice and/or reconciliation, with the aim of healing individuals and rebuilding relationships and communities; the TRC set up in post-apartheid South Africa is just one example. Some transitional processes involve a combination of both retributive and restorative justice. In Sierra Leone, a Special Court and a TRC operated alongside each other; and in Rwanda, the traditional gacaca community justice process (see Chapter 4 ) that combined retributive and restorative justice aims was adapted to deal with the crimes of the genocide. 
Reparative justice, another key approach to justice, seeks to repair the damage of the past through measures such as payment of compensation to victims or collective reparations in the form of projects to benefit the community. An example of reparative justice is the moral reparations pursued in the framework of the Extraordinary Chambers in the Courts of Cambodia (ECCC) in relation to human rights violations committed by the Khmer Rouge regime (see Chapter 7). Teitel (2000: 119) lists a number of measures that can be classified as contributing to what she calls reparatory justice, including reparations, damages, remedies, redress, restitution, compensation, rehabilitation and tribute.

With a more forward-oriented focus, distributive or socio-economic justice has been identified as important for building a future that goes beyond protecting civil and political rights and also addresses cultural, social and economic rights (Lambourne, 2014a; Mani, 2002). This is consistent with building a 'positive peace' that addresses the root causes of conflict and promotes a more politically and socio-economically just future, rather than simply a 'negative peace' that seeks to end the direct violence of war and mass atrocities (Galtung, 1969). Guatemala has been cited as an example where this approach was prioritised and where the pursuit of accountability for the crimes of former leaders existed alongside institutional and socio-economic provisions aimed at addressing the underlying causes of the conflict (Mani, 2002: 165).

The term 'historical justice' is used to encompass situations where the focus is not on transition per se, but rather on seeking redress for historical wrongs that are transmitted across generations through collective memory and memory practices. Examples include abuses committed in the context of colonisation and human rights violations against Indigenous peoples (Neumann and Thompson, 2015). Teitel (2000) uses historical justice as a term to frame the need for truth - a need that is often the primary driver for the creation of different types of historical commissions or truth commissions as defined and examined in theory and practice by Hayner (2011). The pursuit of the truth in the form of an account of historical wrongdoings is frequently combined with a restorative or reconciliatory focus in the form of a TRC as a particular form of truth commission (Hayner, 2011: 12). The aforementioned TRCs in South Africa and Canada are two such examples that focused on revealing the truth and promoting reconciliation for past wrongs. Additionally, the concept of historical justice goes beyond the idea of individual criminal justice to recognise the need for collective forms of accountability to match the collective nature of the crimes committed (Teitel, 2000: 75). This may take the form of political justice or rectificatory or corrective justice (Butt, 2015: 171). 


\section{TRANSITIONAL JUSTICE AND PEACEBUILDING}

Notwithstanding the range of approaches to justice outlined above, transitional justice in practice has often been limited to a legal retributive approach, especially where practitioners follow the model of transitional justice promulgated by the UN (2004, 2010). Transitional justice, as part of a post-conflict peacebuilding agenda, has been pursued by the UN based on a 'one-size-fitsall' model of liberal democratic reforms and mechanisms designed to support individual accountability and the rule of law. The perception of a duty to prosecute in international law, as espoused by Orentlicher $(1997,2007)$, has manifested in a commitment to international criminal justice as the primary means of implementing transitional justice - what Drumbl (2002: 8) has described as the 'hegemonic imperative to implement criminal trials' and Sikkink (2011) later characterised as the 'justice cascade'.

Under international criminal law, criminal responsibility is assigned to individuals for particularly serious violations of human rights defined in international law as war crimes, crimes against humanity and genocide (sometimes grouped together as mass atrocity crimes). These international mass atrocity crimes can be prosecuted in international, hybrid (a mixture of international and national laws) or regional courts, or in national courts where states have enacted domestic legislation to criminalise such violations of human rights and the laws of war. They can also be prosecuted under the provisions of universal jurisdiction.

Following the precedent of the post-World War II trials at Nuremberg and in Tokyo, the two ad hoc international criminal tribunals for the former Yugoslavia and Rwanda, respectively, were created by the UN Security Council in the early 1990s, when the freedoms of the end of the Cold War enabled agreement to be reached on such measures intended to restore international peace and security. International prosecutions have been pursued as part of transitional justice in order to provide accountability for past atrocities, build peace and prevent future atrocities through combating impunity and promoting justice, reconciliation and the rule of law, at least in theory, if not in practice (UN, 2004).

The 'duty to prosecute' was derived from the 'right to justice', which former French jurist and human rights defender Louis Joinet determined was one of four 'Principles against Impunity' in his famous report to the UN Human Rights Commission (UN, 1997). These four principles - namely, the right to know, the right to justice, the right to reparation and guarantees of non-recurrence - were translated into the UN's four key pillars of transitional justice: prosecution initiatives, truth-seeking processes, reparation programmes and institutional 
reform (UN, 2010). In this politico-legal context, justice is assumed to mean legal justice in the form of prosecutions and punishment (i.e., retributive justice), which is intended to deter future war criminals and thus contribute to the fourth aforementioned principle of guarantees of non-recurrence. From this perspective, the future orientation of transitional justice is thus limited to rebuilding the rule of law and implementing institutional reform as a further means of ensuring non-repetition of past human rights violations.

However, while the 'right to justice' has been seen as paramount by the UN and other international actors, including the International Center for Transitional Justice (ICTJ), the 'right to know' through truth-seeking processes has also risen to prominence in the form of the truth commission (Hayner, 2011). The truth commission, like the criminal court or tribunal, is a mechanism representing a programmatic approach to transitional justice adopted by countries in order to deal with a history of past mass human rights violations, with or without the involvement of the international community. Originally associated with amnesties and the perpetuation of a culture of impunity, the early truth commissions of the 199os were seen as representing a political compromise of revealing the truth in exchange for justice where 'political resistance to accountability was high' (Hayner, 2011: 91). A clear example of this is the case of El Salvador, where a blanket amnesty was passed into law following the release of the country's truth commission report in 1993 (Hayner, 2011: 102). In other cases, de facto blanket amnesties would result when no formal transitional justice was pursued, such as in post-civil war Angola and Mozambique (Olsen et al., 2010: 40).

The South African TRC, with its innovative approach of providing individual conditional amnesty rather than blanket amnesty (Hayner, 2011: 29), challenged this perception of compromise between justice and truth. Its emphasis on restorative justice as an alternative form of justice took a more forward-looking approach, aimed at rebuilding a new 'rainbow nation' by transforming the relationship between black and white South Africans through healing, forgiveness and reconciliation (Tutu, 1999: 51-52). The South African TRC also expanded notions of truth beyond victims' right to know the factual and forensic truth of what happened, to their own narrative truths and personal stories of what happened to them. By providing a public space for the expression of these personal/narrative truths, the South African TRC was seen as facilitating the creation of a shared social or dialogical truth that contributed to an experience of restorative or healing truth, thus expanding the 'right to know' from a historical concept to a future-oriented process of healing and reconciliation (Boraine, 2006). 
As outlined by Hayner (2011), most truth commissions subsequently have called for prosecutions in their final report, and the use of amnesties has become less common, even though the political constraints on pursuing accountability have remained in such countries as Burundi and Sri Lanka, where truth commissions have been established but a culture of impunity prevails. In other cases, truth commissions have not precluded the pursuit of criminal prosecutions, as in post-civil war Sierra Leone (Ainley et al., 2015).

The 'right to reparation' has similarly undergone an evolution in transitional justice, from the original focus on seeking material compensation and payments to individuals through reparation programmes to a more pragmatic emphasis on the concept of moral or collective reparations, as illustrated by the example of the ECCC mentioned earlier. Laplante (2014) offers a justice continuum model of reparations, which starts at the narrowest end with reparative justice linked to the classical tradition of corrective justice through civil remedies or material compensation for specific harms or losses, as pursued in a number of cases including Chile and Morocco. Next in the continuum is restorative justice, involving the participation of victims as stakeholders and a focus on restoring their dignity and local ownership in the reparations process, as seen in many traditional customary practices, such as the nahe biti process incorporated into the East Timorese Commission for Reception, Truth and Reconciliation (CAVR) (Babo-Soares, 2004). This is followed by what Laplante (2014: 74) identifies as a civic justice approach, which moves beyond the micro-level reconciliation inherent in the restorative justice approach to a focus on the macro-level relationship between the government and the governed' and the potential for political transformation, as seen in the Peruvian reparations programme. Finally, at the broadest end of the spectrum, socio-economic justice, according to Laplante (2014: 77), provides the opportunity for reparations to 'remedy historical social and economic inequalities' and contribute to distributive justice that links directly to the goals of sustainable peacebuilding and transformative justice (Lambourne, 2009, 2014a), as discussed later in this chapter.

Despite developments in transitional justice focusing on broader understandings of truth, justice and reparations that are more consistent with building peace and reconciliation, they have remained secondary to the overriding imperative to pursue retributive justice and factual/forensic truth through criminal prosecutions as a means of fulfilling the 'right to justice' principle. There are, however, signs that this could be changing if transitional justice follows the same path as peacebuilding in its turn away from liberal democratic programmatic responses towards a more pragmatic approach associated with building local resilience to future crises (Chandler, 2017; de 
Coning, 2016; Juncos and Joseph, 2020). As explained by de Coning (2016: 167), this new focus on pragmatic peacebuilding:

... is shifting the debate away from liberal top-down problem-solving approaches towards more pluralistic bottom-up, or hybrid, conflict management approaches that do not have the ambition to resolve conflict, but instead invest in the resilience of local social institutions to prevent, cope with and recover from conflict, i.e. to sustain peace.

This so-called pragmatic turn in peacebuilding can be related to the "transformative turn' in transitional justice, in which scholars have proposed alternative approaches to justice that go beyond those promulgated by the UN's model of transitional justice with its emphasis on programmatic responses to support the four key pillars - prosecutions, truth, reparations and institutional reform. Accordingly, before moving to a discussion about the implications of different types of resilience thinking for transitional justice, the next section will first examine how notions of transformative justice have evolved to challenge the dominant politico-legal, prosecutorial approach to transitional justice.

\section{THE TRANSFORMATIVE TURN IN TRANSITIONAL JUSTICE}

Daly (2002) first proposed the idea of transformative justice as a means of recognising the transformative agenda inherent in transitional justice and supporting the social transformation necessary to meet the goals of reconciliation and deterrence. According to her:

Simply changing the governors won't cure a problem that resides as well in the governed. ... This entails not just a transition, but rather a transformation. Transition suggests movement from one thing to another - from oppression to liberation, from oligarchy to democracy, from lawlessness to due process, from injustice to justice. Transformation, however, suggests that the thing that is moving from one place to another is itself changing as it proceeds through the transition; it can be thought of as radical change (Daly, 2002: 74).

As part of this transformative agenda, Daly (2002) proposed the need to consider other forms of response extending beyond retributive justice for individual harms to address different types of injustices - including collective economic or political injustices, as in South Africa. Lambourne (2009, 2014a) built on this idea of a transformative agenda to incorporate different types of justice in her model of transformative justice: legal (including both retributive and restorative) justice; socio-economic justice; political justice; and psychosocial justice 
and healing derived from truth, comprising both knowledge of what happened and acknowledgement that what happened was wrong.

Similar to Daly (2002: 92), Lambourne's model (2009, 2014a) was predicated on the need for a transformation that goes beyond the narrow confines of a transitional moment to a more pervasive transformation of society that would respond to the priorities of a particular cultural and conflict context, consistent with Ungar's (2008) emphasis on the critical role of cultural context in determining levels of resilience in at-risk populations. More specifically, Lambourne's model of transformative justice underlined that justice must be seen as more than transitional. It must set up structures, institutions and relationships to promote transformation and sustainability (Lambourne, 2009, 2014a).

Both Daly's (2002) and Lambourne's (2009) work also emphasises reconciliation as a process and outcome. For Lambourne (2009), this means paying attention to relational or psychosocial as well as structural transformation, consistent with Lederach's $(1995,1997)$ theories of conflict transformation and peacebuilding. In considering how justice can contribute to building inclusive political communities after war and other mass violence, Mani (2002: 15) identifies peacebuilding as a dynamic, social and associative process that rebuilds fractured relationships between people'. However, in the face of ongoing controversy about the definition of reconciliation and its relevance to macro-level peacebuilding and transitional justice, reconciliation as a concept has been marginalised in the UN model and in subsequent transitional justice practice (Lambourne, 2014b; UN, 2010). Despite being mentioned as a goal in the UN Secretary-General's 2004 report to the UN Security Council on the rule of law and transitional justice (UN, 2004), it is notably absent from the four key pillars subsequently outlined by the UN (2010). However, in reflecting on the pragmatic turn in peacebuilding towards a focus on sustaining peace, the UN (2015) mentions the role of reconciliation in local communities and maintains that "efforts to sustain peace must build upon [local] institutions and the resilience and reconciliation processes of local communities, and not undermine them'. This perspective on sustaining peace in practice is thus consistent with the transformative turn in transitional justice advocated by both Daly (2002: 92) and Lambourne (2014a).

Gready and Robins (2014) and Evans (2016) have proposed a narrower conception of transformative justice, based on a human rights perspective that argues for a greater emphasis on socio-economic rights in addition to civil and political rights, but without considering the potential for relational or psychosocial transformation proposed by Lambourne (2014a), and without placing the same accent on reconciliation as both Daly (2002) and 
Lambourne (2014a). Gready and Robins (2019: 33) situate their proposal for a transformative approach to transitional justice within a critique of the foundational limitations of transitional justice, linking it to liberal and neoliberal conceptions of human rights. They cite two strands of globalisation underpinning this critique: the privileging of 'liberal paradigms of civil and political rights through an emphasis on elections, procedural democracy, constitutionalism and the rule of law, and various backward-looking truth and justice measures' along with 'market-driven, neoliberal economics' (Gready and Robins, 2019: 33).

McAuliffe (2017) underscores the potential of transformative justice for redressing the marginalisation of socio-economic issues as root causes of conflict (see also Evans, 2016). He explicitly links transformative justice to the local turn in peacebuilding and transitional justice, which he describes as promising in 'accordance with social needs, sustainability and transformation of social structures' (McAuliffe, 2017: 233). McAuliffe (2017: 246) cites examples of micro-level programmes developed independently of the state, such as Fambul Tok in Sierra Leone where a local and an international non-governmental organisation (NGO) collaborated to provide opportunities for village-level community healing and reconciliation following the civil war (Martin, 2020). Fambul Tok was later adapted to support local capacity-building in response to the failures of state institutions in responding to the Ebola crisis, focusing specifically on the importance of empowering local communities to selforganise as a means of sustaining peace (de Coning, 2016: 173). The example of Fambul Tok illustrates the potential for a transformative justice framework to address structural violence, thereby contributing to the building of community resilience - defined by Saul (2014: 8) as 'a community's capacity, hope and faith to withstand major trauma and loss, overcome adversity, and to prevail, usually with increased resources, competence and connectedness'.

Transformative justice theories thus criticise the emphasis on top-down, elite-driven policies and programmes implemented as part of transitional justice and focus more on the needs and priorities of the local affected communities (Evans, 2019). According to Gready and Robins (2014: 340), 'transformative justice entails a shift in focus from the legal to the social and political, and from the state and institutions to communities and everyday concerns'. Accordingly, and consistent with resilience thinking, 'transformative justice is not the result of a top-down imposition of external legal frameworks or institutional templates, but of a more bottom-up understanding and analysis of the lives and needs of populations' (Gready and Robins, 2014: 340). 
Lambourne (2009, 2014a) developed her model of transformative justice inductively ${ }^{1}$ by studying and listening to the voices of survivors of mass violence and atrocities who identified the types of justice that were important to them, and by observing micro-level peacebuilding and community practices that focus on healing and reconciliation (Lambourne and Niyonzima, 2016). The lived realities of affected communities suggest that transitional justice at the formal, elite level of tribunals and truth commissions is insufficient to meet their justice needs and interests (Lambourne, 2014a, 2014c). Local communities recognise the need to live together after mass violence and human rights violations and to focus therefore on pursuing programmes that build their socio-economic and psychosocial capacities. From a grassroots perspective, peace and reconciliation are no longer abstract concepts to be debated but essential means of survival, achieved through types of justice that build local resilience and do more to unite than to divide.

The local turn in transitional justice described here mirrors that in peacebuilding, with its focus on local participation and empowerment (Lambourne, 2014a; Robins, 2019). As such, it also invites the same criticisms regarding the lack of interrogation of the local - what it means and how it manifests in numerous guises which may or may not support a progressive agenda of equity, inclusiveness and participation at that local/community level. McAuliffe (2017: 283), for example, elaborates on the limits to the transformative potential of localised or bottom-up approaches to transitional justice and peacebuilding; 'peaceful individuals or peaceful communities do not automatically make peaceful societies or states'. According to him, the transformative process advocated by theorists such as Lambourne (2014a) and Evans (2016) does not in practice result in transformative outcomes because it ignores the realities of elite power over domestic politics. He argues that the inclusion of affected communities cannot in itself influence the policies and practices of elites and thus cannot transform socio-economic structures without a focus on what he calls the 'missing middle' and a process of vertical integration linking the local community with the state (McAuliffe, 2017: 280).

Robins (2019: 304) addresses this critique by suggesting that 'transformative participation demands an engagement of communities with institutions of the state and with national and international NGOs, that transforms the relationship from which it emerges'. This is another way of articulating the concept of relational transformation as advocated by Lambourne (2014a) in her model of

1 Based on extensive fieldwork conducted over twenty years at different times in Burundi, Cambodia, East Timor, Rwanda, Sierra Leone and South Africa. 
transformative justice - a process that transforms power relationships (see also Lambourne and Rodriguez Carreon, 2016: 90). While Waldorf (2012) has criticised transformative justice as being too all-encompassing and ambitious, Robins (2019) proposes a more transformative understanding of justice as emerging from social practice, rather than framed against an ideal of justice. ‘This approach', he argues, 'perceives ideas of justice not as something circumscribed by legal instruments and a technocratic expert practice, but as emerging directly from action or struggle, created collectively and democratically in claimed spaces' (Robins, 2019: 302). Abe (2018) goes further, highlighting a more anarchical process at the local level that sees social recovery emerging from 'meaning-making' in accidental and ad hoc ways. The idea of 'planning for the unplanned' (Abe, 2018: 206) might sound paradoxical, yet is entirely consistent with resilience thinking and the notion of adapting to complexity and uncertainty (de Coning, 2018). Hoddy and Gready (2020: 3), meanwhile, situate transformative justice within a framework of critical social theory, systems thinking and complexity theory, claiming that:

What is missing from this literature is the place of critical theorising in transformative practice, that is, where new knowledge is developed about the social systems where change is sought, and how these systems disempower and constrain, and how these features might be challenged.

Historical or intergenerational injustices also speak to the benefits of adding a transformative lens to ideas of transitional justice. Applying this lens to the legacies of colonialism and violations of Indigenous rights, for example, amplifies the intergenerational impacts of trauma and discrimination that affect the psychosocial well-being and socio-economic chances of subsequent generations. Maddison and Shepherd (2014) thus argue for an extension of the concept of transition, to enable proper accounting for colonial violence. In this way, they propose a post-colonial re-visioning of transitional justice that offers possibilities for deep social transformation at both the national and international levels.

The emergence of a transformative agenda for transitional justice has therefore turned a spotlight on local capacity building and systemic societal transformation, linked to the application of resilience thinking to transitional justice and peacebuilding. The psychosocial and relational aspects of transformative justice also speak to the potential contribution of a resiliencebuilding approach to complement the more programmatic, institution-based agenda in transitional justice, albeit subject to potential critique if they focus only on supporting communities to adapt to crises - rather than taking steps to remove the sources and prevent such crises from recurring. 


\section{RESILIENCE THINKING, TRANSITIONAL JUSTICE AND TRANSFORMATION}

The emergence of resilience thinking reflects the shift from a programmatic liberal peacebuilding model to a more pragmatic or adaptive means of rebuilding the capacity of societies to respond to complexity and uncertainty (de Coning, 2018). In the field of transitional justice, scholars have just begun to grapple with the relevance and risks associated with different conceptualisations of resilience (Kastner, 2020; Wiebelhaus-Brahm, 2017). While resilience thinking may seem consistent with the transformative turn in transitional justice, it too has been criticised as prioritising localised bottom-up approaches that cannot succeed in the face of elite intransigence and continuing politico-legal and socio-economic structures of discrimination and oppression (Chandler, 2020).

Yet, at the same time, localised transformative processes can help build individual and community resilience to better deal with surrounding threats from elite actors and state-level institutions, which, through active oppression or neglect, undermine the well-being of local communities. In this sense, emerging understandings of resilience as a negotiated process which is sensitive to contextualised challenges have become increasingly relevant to adaptive peacebuilding efforts which are synonymous with new ways of doing transitional justice. As Kastner argues (2020: 383 ), a resilience approach to transitional justice 'shifts the focus from short-term objectives, such as obtaining a certain number of convictions before a criminal tribunal, to gradually (re)building relationships and social capital', consistent with models of transformative justice discussed in the previous section. As the chapters in this volume show, these efforts can begin at the level of individuals and communities who resist oppressive definitions of their experiences of injustice (see, for example, Nayanika Mookherjee's discussion of Bangladesh's birangonas or 'war heroines', Chapter 6), or they can be led by governments aiming to restore social and political stability.

At its simplest level, resilience is about the ability of systems - whether social, economic, political or environmental systems - to recover from crises (Ungar, 2021). Juncos and Joseph (2020: 294) cite the systemic approach of resilience thinking as an advantage over standard liberal peacebuilding as it 'goes beyond the project-driven and silo approaches of the past towards the transformation of entire systems or regimes'. As Ungar's explanation of a socialecological definition of resilience in Chapter 1 shows, applying resilience thinking to the peacebuilding and transitional justice context raises the possibility that addressing the sources of resilience at multiple systemic levels is 
critical to both individual and societal recovery and transformation postconflict.

There is a danger, however, with using resilience as a principle for societal reconstruction and justice. Just as the transformative turn in transitional justice has caused some to focus too much on local capacities to manage threats and adapt to complexity and change, a decontextualised, highly psychologised conception of personal resilience ignores power relations and fails to engage with the root causes of vulnerability (Kastner, 2020: 373). Adaptation, for example, can be seen as implying transformation at the micro level of individuals and local communities and a lack of focus on challenging the political and economic structures that contributed to the root causes of the violence, which is already something that is insufficiently addressed in transitional justice. Like transitional justice, resilience is better understood as a systemic process that implicates both individuals and the social and institutional structures that either oppress or liberate.

Ungar and Theron's (2020) ecological and multi-systemic model of resilience, referred to in the previous chapter, suggests new ways of thinking about transitional justice and its contribution to building democratic and peaceful futures - both incorporating yet also going beyond the turn to the local in peacebuilding and transitional justice. Transitional justice, although concerned with the past, must also focus on the future; while dealing with divisions from the past, it must build cooperative relationships for the future; while dealing with past crimes and root causes of violent conflict, it must heal wounds, redress harms, transform power relations and build new socioeconomic and politico-legal structures that focus on attaining and protecting human rights in the future.

Therefore, the idea of resilience in relation to transitional justice is intimately connected with the liminal space of a transition towards peace and democracy. Resilience can be built through a willingness to take responsibility for the past, at the same time as reconciling with those who have committed atrocities. It involves embracing a future peaceful relationship between those defined as perpetrators and those defined as victims or survivors and committing to working together to build and maintain not only individual well-being, but also the social, political, legal, economic and environmental structures to support a sustainable peace with justice. This requires a reckoning with the past based on accountability and taking responsibility, combined with the willingness and strength - both individual and collective - to face, if not embrace, the possibility of a different future. In this sense, resilience, like peacebuilding and transitional justice, must attend to the transformation of multiple systems at once. 
While this may be an argument in favour of integrating resilience thinking with approaches to transitional justice, Kastner (2020) offers a cautionary note. Resilience thinking can be in conflict with the transitional justice approach of dealing with the past in order to build a peaceful future. As he sees it, resilience is about breaking from the past, while transitional justice is explicitly concerned with such processes as establishing accountability, memorialising, repairing the damages and telling the truth about past experiences of human rights atrocities (Kastner, 2020: 369). Kastner (2020: 374) goes further, arguing that the traditional goals of transitional justice - 'revealing the truth, holding perpetrators accountable and trying to provide some sense of justice for the victims' - are 'made redundant in a resilience paradigm' that focuses only on the future rather than on addressing the past in order to build a better future. Furthermore, Kastner (2020: 374) maintains that "resilient individuals and communities may never be able to address systemic factors or the responsibilities of external actors, which will largely remain beyond their scope of influence and "agential capacities".

Wiebelhaus-Brahm (2017: 159), meanwhile, retains a more optimistic perspective and concludes by arguing for a long-term commitment to the promotion of resilience and transitional justice as 'gradual, complex transformations' that are context-sensitive and understand existing capacities in order to respond with 'policy interventions that will address local needs'. By envisaging a long-term transformation, he is also tapping into the potential of a transformative justice approach that strives for structural transformation over and above individual and community resilience.

This potential is reflected in considerations of the relationship between resilience and peacebuilding. Pouligny (2014) proposes that we think of resilience as providing protective factors to counter-balance risk factors, as part of a dynamic process of experiencing and responding to violence at multiple systemic levels. As Pouligny (2014: 2 ) argues, 'violence transforms as much as it destroys. It creates new realities and forms of relationships'. Peacebuilding, seen as an intervention to support further transformation, thus plays a powerful role in the trajectory of post-violence relationships, as much as it does in transforming structures and institutions.

This broader societal resilience can be developed through giving attention to interventions that support the building of social cohesion and social capital, defined by Bourdieu as 'the aggregate of the actual or potential resources that are linked to the possession of a sustainable network of relationships' (cited in Saul, 2014: 10). The different dimensions of social capital are directly linked to protective factors that contribute to sustaining individual agency and empowerment in a context of strong and supportive inter-linkages horizontally 
within (bonding social capital) and between communities (bridging social capital), and vertically between individuals, communities and the state (linking social capital) (Bartolomei et al., 2013; Putnam, 2000). Relationships and social networks thus create the potential for social mobilisation, which, in turn, creates the possibility for social change, thus illustrating how individual and community resilience can contribute to building societal and state resilience.

Resilience is therefore more than a passive protective factor that enables individuals and communities to recover from stressful events such as mass violence. It also suggests an essential agentic quality that enables individuals and communities - and organisations - to adapt and evolve as necessary to maintain functionality beyond mere survival and to effect social change. This approach is reflected in Pouligny's (2014: 1) definition of societal resilience: 'the capacity of a group, community, or society at large to cope with stresses and disturbances as a result of social, political, and environmental change and adjust while still retaining essentially the same functions and feedbacks by the people'. She places emphasis on the resilience of a system based on its functions and capacities to perform, not on its stability.

According to Kastner (2020: 372), when resilience thinking is used in a more progressive way, it 'carries connotations of flexibility and reflexivity, capacity, agency and empowerment'; and, furthermore, it suggests that 'crises may even represent opportunities to implement innovative change'. At the same time, he points out that resilience thinking that focuses on 'flexibility, diversity and adaptive governance appears diametrically opposed to the currently dominant transitional justice paradigm' (Kastner, 2020: 382 ). Rather, it supports the local, participatory turn in transitional justice (McEvoy and McGregor, 2008; Shaw and Waldorf, 2010) that eschews a one-size-fits-all approach to imposing models of transitional justice and 'should be concerned with local understandings of justice and the transformative capacity of the individuals and communities primarily concerned' with a focus on 'facilitating, rather than producing, justice' (Kastner, 2020: 373). As Ungar explains in Chapter 1, resilience can describe a process of transformation that goes beyond recovery and adaptation, given that short-term survival strategies may be maladaptive and adaptation may not be consistent with long-term sustainability.

Civil society peacebuilding organisations have been leading the move towards a networked and transformative approach to resilience that is more applicable in the peacebuilding (and transitional justice) context and should serve to alleviate the risks associated with more traditional resilience thinking. The Geneva Peacebuilding Platform, for example, has focused on the network-driven, informal nature of peacebuilding, rather than the traditional 
system-based understanding of resilience inherited from other disciplines. The Platform suggests that the qualities that make up resilience ... involve dense patterns of trust networks, hybrid coalitions forged across a wide range of actors, shared narratives, common interests, multiple lines of communication, good leadership, and a commitment by local leaders to take risks for peace' (Geneva Peacebuilding Platform, 2013: 6). This is similar to a multi-systemic approach to resilience (Ungar and Theron, 2020).

The following section explores briefly the potential and limitations of different transitional justice mechanisms to build resilience. In so doing, it will take into account a number of key factors, as suggested by Pouligny's (2014: 3) proposed components of a resilient societal system: namely, psychosocial recovery, shared systems of meaning, solidarity among community members, community reintegration and trust, and broad and inclusive forms of governance.

\section{TRANSITIONAL JUSTICE MECHANISMS AND RESILIENCE}

\section{Criminal trials}

The organising and holding of criminal trials can contribute to building individual and community resilience, especially when those accused from a perpetrator group are found guilty and punished. For victims, the acknowledgement that they suffered wrongdoing and harm, and the experience of seeing the perpetrator/s held accountable and punished, can contribute to individual resilience. However, the criminal justice system is generally focused on individual accountability and deterrence rather than systemic transformation, making it incomplete as a resilience-building approach. As suggested by Kastner (2020: 381 ), criminal trials in themselves may undermine resilience if they reinforce divisions in society. Moreover, Wiebelhaus-Brahm (2017: 156) suggests that they may strengthen bonding social capital within one societal group, but without bridging social capital between social groups.

By focusing on individual responsibility rather than collective guilt, criminal trials can help a society to move towards a kind of reconciliation where individuals can rebuild as citizens and survivors, rather than as victims and perpetrators. However, this is only likely to work if it is the leaders who are prosecuted and found individually criminally liable, leaving those remaining to rebuild relationships and functioning political, legal and societal structures. If there are large numbers of perpetrators among the general population, as in Rwanda after the genocide, for example, where thousands of accused génocidaires were imprisoned, a retributive, individual criminal accountability 
approach will be more likely to undermine resilience as it serves only to stigmatise and further divide victims and perpetrators. The Rwandan government recognised this and, rather than continuing to focus only on retributive justice through the domestic courts, it instituted several measures to promote restorative justice and reconciliation in order to rebuild the country on a more sustainable and resilient basis.

Retributive justice through criminal trials can also further re-traumatise victims and witnesses when they are required to re-tell or re-live the traumatic events. Ungar (Chapter 1) argues that 'criminal trials to address war crimes may become extremely divisive for communities, disrupting social cohesion or even traumatising some victims, even as they appear to re-establish order with regard to governance and the rule of law'. Janine Natalya Clark also demonstrates this in her chapter on Bosnia-Herzegovina (Chapter 3). Criminal trials can therefore sometimes do more to undermine than to build individual and community resilience.

Furthermore, the imposition of criminal prosecutions can be criticised as encroaching on local agency and participation, thereby undermining resilience. International criminal justice can be viewed as part of the neo-liberal agenda that values individual accountability through state-driven, top-down processes, rather than bottom-up, communitarian approaches to locally meaningful justice and reconciliation processes. On the other hand, there can be long-term local benefits of criminal prosecutions, especially in the context of nationally located hybrid courts - like the Special Court for Sierra Leone (SCSL) and the ECCC (UN, 2004: para. 44). International involvement in these hybrid courts has sought to strengthen domestic legal systems and judicial capacity in order to leave a lasting legacy.

The capacity-building legacy of such courts, therefore, can potentially contribute to building resilience through promotion of the rule of law, but only if supported by systemic political transformation and associated institutional reform. Considering hybrid courts' interaction with other systems suggests that politico-legal transformation alone is unlikely to have an impact on long-term resilience without attention to psychosocial transformation through healing and reconciliation and a holistic approach to transitional justice, as discussed earlier in relation to some models of transformative justice.

\section{Truth commissions}

Truth commission goals of truth-seeking, truth-telling and truth recovery sometimes but not always alongside reconciliation in a TRC - can be seen as 
a means of supporting individual and community resilience by building social cohesion and social capital. As argued by Wiebelhaus-Brahm (2017), truth commissions that explicitly promote reconciliation can promote resilience through building empathy to support relational transformation and bridging social capital, at the same time as reinforcing bonding capital. Furthermore, truth commissions have the potential to support political and social change, through the implementation of report recommendations that address root causes and the need for structural transformation via institutional reform to underpin state and societal resilience.

Applying the four types of truth defined by the South African TRC, enabling victims to tell their story about what happened to them can enable a truth commission to compile a historical account of multiple personal/narrative truths that can shed light on the factual/forensic truth. It can also contribute to the establishment of a social/dialogical shared truth, and, potentially, to a healing/restorative truth, depending on the context of the particular truth commission.

Clark (2020) has argued that giving victims more opportunity to control how they tell their stories as part of a transitional justice process can assist with narrative plasticity, and hence with adaptability and resilience. Narrative plasticity is more likely to develop in bottom-up, community-based processes than in the kinds of mechanisms set up by governments and the international community, such as criminal tribunals and truth commissions. This is especially true in criminal trials, for example, where victims are only allowed to appear as witnesses (although proceedings at the ECCC and the International Criminal Court offer victims a more expansive role) and to respond to questions intended to establish the guilt or innocence of the accused. Even in truth commissions, the structure determines the way in which victims are able to tell their story, thereby limiting the potential resilience-building impact.

\section{Reparations}

Reparations can contribute to individual, community and societal resilience if they facilitate socio-economic justice for individuals and communities in order to meet their basic needs and ability to recover and adapt to crises. However, this is rarely the case in practice, as both perpetrators and states alike have failed in their capacity to adequately compensate victims for past material and psychological harms. Reparations are more likely to be symbolic than sufficiently meaningful to effect real change in the socio-economic realities of survivors of mass violence. Moral and collective reparations may be seen as 
having a greater potential for building resilience, such as in the case of the ECCC's provision of moral reparations in the form of trauma recovery programmes that support psychosocial healing and transformation (Lambourne, 2014c; see also Chapter 7). Another example was Peru's collective reparations programme that included financing small development projects, in addition to commemorative events for victims and survivors (Garcia-Godos, 2017: 194-195).

As previously discussed, a number of scholars have argued for distributive and socio-economic justice to be included as part of a transformative approach to transitional justice, in order to address root causes such as poverty and relative deprivation and the potential for future violence. Such an approach would be consistent with a transformative approach to resilience that avoids returning to a status quo of exploitative power relations and structures that inhibit individual agency and empowerment.

\section{Indigenous customary practices}

Customary practices may afford greater legitimacy than top-down, externally driven transitional justice mechanisms. By drawing on the strengths and capacities of local communities, traditional or customary practices both reflect and help to foster resilience. On the other hand, the implementation of customary practices can potentially undermine resilience, by entrenching existing inequalities and 'reinforcing patriarchy and further empowering illegitimate, ineffective power structures at the local level' (WiebelhausBrahm, 2017: 157). They are also unlikely to be able to affect state or societal structures and institutions responsible for past and/or ongoing human rights violations unless accompanied by initiatives to strengthen linking as well as bonding and bridging social capital.

Traditional practices often focus on healing, reconciliation, reintegration and restoration of the community, and thus can contribute to both individual and community resilience. For example, in the context of the CAVR in Timor-Leste, the grassroots reconciliation process of nahe biti involved the perpetrator and victim sitting together and reaching a voluntary acceptance of culpability and agreement on reconciliation acts such as reparation, community service or public apology. Nahe biti is usually finalised with a symbolic exchange of 'betel nut' ceremony, to show sincerity and commitment, and is traditionally seen as a bridge to achieve a much greater aim of harmony and peace in the society. The nahe biti process included as part of the CAVR can thus be seen as a means of promoting social cohesion, bonding and bridging social capital to potentially support individual - and especially community resilience as part of transitional justice and peacebuilding. 


\section{Psychosocial healing and reconciliation}

Community-based psychosocial programmes such as Healing of Memories and Alternatives to Violence workshops run by the local NGO Trauma Healing and Reconciliation Services (THARS) in Burundi add to transitional justice and peacebuilding by supporting recovery from trauma, promoting forgiveness and reconciliation, and building empathy and social capital (Lambourne and Niyonzima, 2016). Such programmes thus can directly contribute to building individual and community resilience by promoting individual and collective healing (Saul, 2014).

Rather than conceptualising trauma as a mental illness to be treated through counselling and psychotherapy, a psychosocial healing approach recognises the interconnections between the individual and their relational and structural environment. Community-based psychosocial programmes, such as those pursued by THARS in Burundi, can be seen as assisting the individual to recover from trauma through the stages proposed by Herman (1997): by providing safety, acknowledgement and an opportunity to reconnect with others through sharing stories and activities that help to build empathy, hope and a shared commitment to a peaceful future together. Such psychosocial healing and relational transformation at the interpersonal and community level can potentially build resilience and contribute to transformative justice (Lambourne, 2014a).

According to Herman (1997: 183), acknowledgement, remembrance and mourning can help to transform traumatic memory by enabling survivors to tell or reconstruct the story in a safe or protected relationship or therapeutic space. Trauma-healing workshops can provide a similar function, in addition to enabling acknowledgement and reconnection through the community group process, thereby addressing the social and relational dimensions of the traumatic experience through helping to rebuild trust and empathy (Herman, 1997; Lambourne and Niyonzima, 2016). Such programmes can also provide the opportunity for survivors (including both victims and perpetrators) to regain their agency through social, economic and political empowerment and social action (Herman, 1997: 207; Lambourne and Niyonzima, 2016). This step can further contribute to sustaining resilience in communities through the transformation of relationships and building of linking social capital with local and political leaders, with the aim of affecting socioeconomic and political transformation. However, the potential impact of such bottom-up processes in Burundi has been severely limited by the elite political control of governance structures and lack of political commitment to societal transformation to support peacebuilding and transitional justice. 


\section{CONCLUSION}

This chapter has raised questions about the adequacy of the politico-legal transitional justice framework for promoting resilience in societies recovering from mass atrocities and human rights violations. The strong focus of transitional justice on criminal legal accountability for perpetrators of mass human rights violations and on rebuilding the rule of law to support a democratic political transition reflects the technical, programmatic approach to peacebuilding criticised by scholars such as de Coning (2018). Such an approach is insufficient on its own to promote resilience and adaptive peacebuilding. This chapter argues that socio-economic and psychosocial transformation are critical components of a transformative and networked resilience approach to transitional justice that addresses root causes, responds to the past trauma of mass atrocities and ongoing trauma of relative and absolute poverty and deprivation, and (re)builds relationships in communities and throughout the political system.

The chapter has explored some of the potential opportunities and risks associated with resilience thinking in relation to transitional justice and its connection with adaptive peacebuilding. It has also sought to demonstrate that building resilience is more a function of how transitional justice is approached than the content of any transitional justice programme. In other words, process is more important than the type of mechanism employed. A transformative approach to transitional justice incorporates this emphasis on process, consistent with scholarship that has argued for the importance of participation, agency and empowerment at the local level.

Questions remain, however, about how best to facilitate local participation in transitional justice and peacebuilding processes in the context of new resilience thinking. For example, what happens when facilitation of endogenous, locally driven approaches to building peace and justice is prioritised over local participation in elite-driven, state-based mechanisms, such as criminal trials and truth commissions? Can ideas of local community and individual resilience transcend traditional resilience thinking, in order to develop into a networked and transformative approach to peacebuilding and transitional justice that seeks to do more than 'bounce back' from crises and instead attempts to influence structural politico-legal and socio-economic transformation? Finally, how does this connect in practice with de Coning's (2018: 305) concept of adaptive peacebuilding as an iterative, relational and transformative process 'informed by concepts of complexity, resilience and local ownership'? 


\section{REFERENCES}

Abe, T. (2018). Unintended Consequences in Transitional Justice: Social Recovery at the Local Level. Boulder, CO: Lynne Rienner.

Ainley, K., Friedman, R. and Mahony, C. (eds.) (2015). Evaluating Transitional Justice: Accountability and Peacebuilding in Post-Conflict Sierra Leone. London: Palgrave Macmillan.

Babo-Soares, D. (2004). Nahe biti: The philosophy and process of grassroots reconciliation (and justice) in East Timor. Asia Pacific Journal of Anthropology, 5 (1), 15-33.

Bartolomei, L., Pittaway, E. and Ward, K. (2013). 'The Glue that Binds': The Social Capital Evaluation Tool. Sydney: STARTTS and UNSW Centre for Refugee Research.

Boraine, A. (2006). Defining transitional justice: Tolerance in the search for justice and peace. In A. Boraine and S. Valentine (eds.), Transitional Justice and Human Security. Cape Town: International Center for Transitional Justice, pp. 22-37.

Burgess, P. (2006). A new approach to restorative justice: East Timor's community reconciliation process. In N. Roht-Arriaza and J. Mariexcurrena (eds.), Transitional Justice in the Twenty-First Century: Beyond Truth versus Justice. Cambridge: Cambridge University Press, pp. 176-205.

Butt, D. (2015). Historical justice in postcolonial contexts. In K. Neumann and J. Thompson (eds.), Historical Justice and Memory. Madison, WI: University of Wisconsin Press, pp. 166-184.

Chandler, D. (2017). The rise of resilience. In Peacebuilding: The Twenty Years' Crisis, 1997-2017. Cham, Switzerland: Palgrave Macmillan/Springer, pp. 165-187.

Chandler, D. (2020). Security through societal resilience: Contemporary challenges in the Anthropocene. Contemporary Security Policy, 41(2), 195-214.

Clark, J. (2020). Storytelling, resilience and transitional justice: Reversing narrative social bulimia. Theoretical Criminology, https://doi.org/10.1177/1362480620933230

Daly, E. (2002). Transformative justice: Charting a path to reconciliation. International Legal Perspectives, $12(1-2), 73-183$.

de Coning, C. (2016). From peacebuilding to sustaining peace: Implications of complexity for resilience and sustainability. Resilience, 4(3), 166-181.

de Coning, C. (2018). Adaptive peacebuilding. International Affairs, 94(2), 301-317.

Drumbl, M. A. (2002). Restorative justice and collective responsibility: Lessons for and from the Rwandan genocide. Contemporary Justice Review, 5(1), 5-22.

Evans, M. (2016). Structural violence, socioeconomic rights, and transformative justice. Journal of Human Rights, 15(1), 1-20.

Evans, M. (ed.) (2019). Transitional and Transformative Justice: Critical and International Perspectives. New York: Routledge.

Galtung, J. (1969). Violence, peace, and peace research. Journal of Peace Research, 6 (3), $167-191$.

Garcia-Godos, J. (2017). Reparations. In O. Simic (ed.), An Introduction to Transitional Justice. London/New York: Routledge, pp. 177-200.

Geneva Peacebuilding Platform (2013). Making Sense of Resilience in Peacebuilding Contexts: Approaches, Applications, Implications. Geneva: Geneva Peacebuilding Platform. 
Gready, P. and Robins, S. (2014). From transitional to transformative justice: An agenda for practice. International Journal of Transitional Justice, 8(3), 339-361.

Gready, P. and Robins, S. (eds.) (2019). From Transitional to Transformative Justice. Cambridge: Cambridge University Press.

Hayner, P. B. (2011). Unspeakable Truths: Transitional Justice and the Challenge of Truth Commissions. New York/London: Routledge.

Herman, J. (1997). Trauma and Recovery: The Aftermath of Violence - From Domestic Abuse to Political Terror. New York: Basic Books.

Hoddy, E. T. and Gready, P. (2020). From agency to root causes: Addressing structural barriers to transformative justice in transitional and post-conflict settings. Contemporary Social Science, https://doi.org/10.1080/21582041.2020.1812706

International Center for Transitional Justice (2001). What is transitional justice? www .ictj.org/about/transitional-justice (accessed 28 October 2020).

Juncos, A. E. and Joseph, J. (2020). Resilient peace: Exploring the theory and practice of resilience in peacebuilding interventions. Journal of Intervention and Statebuilding, 14(3), 289-302.

Kastner, P. (2020). A resilience approach to transitional justice? Journal of Intervention and Statebuilding, 14(3), 368-388.

Lambourne, W. (2009). Transitional justice and peacebuilding. International Journal of Transitional Justice, 3(1), 28-48.

Lambourne, W. (2014a). Transformative justice, reconciliation and peacebuilding. In S. Buckley Zistel, T. Koloma Beck, C. Braun and F. Mieth (eds.), Transitional Justice Theories. New York: Routledge, pp. 19-39.

Lambourne, W. (2014b). What are the pillars of transitional justice? The United Nations and the justice cascade in Burundi. Macquarie Law Journal, 13, 41-6o.

Lambourne, W. (2014c). Justice after genocide: Impunity and the Extraordinary Chambers in the Courts of Cambodia. Genocide Studies and Prevention, 8(2), Article 7 .

Lambourne, W. and Niyonzima, D. (2016). Breaking cycles of trauma and violence: Psychosocial approaches to healing and reconciliation in Burundi. In P. GobodoMadikizela (ed.), Breaking Intergenerational Cycles of Repetition: A Global Dialogue on Historical Trauma and Memory. Opladen, Germany: Barbara Budrich Publishers, pp. 291-307.

Lambourne, W. and Rodriguez Carreon, V. (2016). Engendering transitional justice: A transformative approach to building peace and attaining human rights for women. Human Rights Review, 17(1), 71-93.

Laplante, L. J. (2014). The plural justice aims of reparations. In S. Buckley Zistel, T. Koloma Beck, C. Braun and F. Mieth (eds.), Transitional Justice Theories. New York: Routledge, pp. 66-84.

Lederach, J. P. (1995). Preparing for Peace: Conflict Transformation Across Cultures. Syracuse, NY: Syracuse University Press.

Lederach, J. P. (1997). Building Peace: Sustainable Reconciliation in Divided Societies. Washington, DC: United States Institute of Peace Press.

McAuliffe, P. (2017). Transformative Transitional Justice and the Malleability of PostConflict States. Cheltenham: Edward Elgar.

McEvoy, K. and McGregor, L. (eds.) (2008). Transitional Justice from Below: Grassroots Activism and the Struggle for Change. Oxford/Portland, OR: Hart Publishing. 
Maddison, S. and Shepherd, L. J. (2014). Peacebuilding and the postcolonial politics of transitional justice. Peacebuilding, 2(3), 253-269.

Mani, R. (2002). Beyond Retribution: Seeking Justice in the Shadows of War. Cambridge: Polity Press.

Martin, L. M. (2020). Deconstructing the local in peacebuilding practice: Representations and realities of Fambul Tok in Sierra Leone. Third World Quarterly, https://doi.org/10.1080/01436597.2020.1825071

Nagy, R. L. (2013). The Scope and Bounds of Transitional Justice and the Canadian Truth and Reconciliation Commission. International Journal of Transitional Justice, $7(1), 52-73$.

Neumann, K. and Thompson, J. (eds.) (2015). Historical Justice and Memory. Madison, WI: University of Wisconsin Press.

Niezen, R. (2013). Truth and Indignation: Canada's Truth and Reconciliation Commission on Indian Residential Schools. Toronto, ON: University of Toronto Press.

Office of the United Nations High Commissioner for Human Rights (2008). Rule-ofLaw Tools for Post-Conflict States: Maximizing the Legacy of Hybrid Courts. New York/Geneva: United Nations.

Olsen, T. D., Payne, L. A. and Reiter, A. G. (2010). Transitional Justice in Balance: Comparing Processes, Weighing Efficacy. Washington, DC: United States Institute of Peace.

Orentlicher, D. F. (1997). Swapping Amnesty for Peace and the Duty to Prosecute Human Rights Crimes. Joumal of International and Comparative Law, 3(2), 713-717.

Orentlicher, D. F. (2007). 'Settling Accounts' revisited: Reconciling global norms with local agency. International Journal of Transitional Justice, 1(1), 10-22.

Pouligny, B. (2014). The Resilience Approach to Peacebuilding: A New Conceptual Framework. Washington, DC: United States Institute of Peace.

Putnam, R. D. (2000). Bowling Alone: The Collapse and Revival of American Community. New York: Simon \& Schuster.

Robins, S. (2019). Conclusion: Toward transformative justice. In P. Gready and S. Robins (eds.), From Transitional to Transformative Justice. Cambridge: Cambridge University Press.

Saul, J. (2014). Collective Trauma, Collective Healing: Promoting Community Resilience in the Aftermath of Disaster. New York/London: Routledge.

Shaw, R. and Waldorf, L. (eds.) (2010). Localizing Transitional Justice: Interventions and Priorities After Mass Violence. Stanford, CA: Stanford University Press.

Sikkink, K. (2011). The Justice Cascade: How Human Rights Prosecutions are Changing World Politics. New York/London: W. W. Norton.

Teitel, R. G. (2000). Transitional Justice. Oxford: Oxford University Press.

Tutu, D. (1999). No Future Without Forgiveness. London: Rider.

Ungar, M. (2008). Resilience across cultures. British Journal of Social Work, $3^{8}$, 218-235.

Ungar, M. (2018). Systemic resilience: Principles and processes for a science of change in contexts of adversity. Ecology and Society, 23(4), 34-50.

Ungar, M. (ed.) (2021). Multisystemic Resilience: Adaptation and Transformation in Contexts of Change. New York: Oxford University Press.

Ungar, M. and Theron, L. (2020). Resilience and mental health: How multisystemic processes contribute to positive outcomes. The Lancet Psychiatry, 7(5), 441-448. 
United Nations. (1997). Question of the Impunity of Perpetrators of Human Rights Violations (Civil and Political): Revised Final Report Prepared by Mr Joinet Pursuant to Sub-Commission Decision 1996/119.

United Nations. (2004). Report of the Secretary-General, The Rule of Law and Transitional Justice in Conflict and Post-Conflict Societies. New York: United Nations Security Council.

United Nations. (2010). Guidance Note of the Secretary-General: United Nations Approach to Transitional Justice. New York: United Nations.

United Nations. (2015). Report of the High-level Independent Panel on Peace Operations on Uniting Our Strengths for Peace: Politics, Partnership and People. General Assembly \& Security Council. A/70/95-S/2015/446.

Waldorf, L. (2012). Anticipating the past: Transitional justice and socio-economic wrongs. Social and Legal Studies, 21(2), 171-186.

Wiebelhaus-Brahm, E. (2017). After shocks: Exploring the relationships between transitional justice and resilience in post-conflict societies. In R. Duthie and P. Seils (eds.), Justice Mosaics: How Context Shapes Transitional Justice in Fractured Societies. New York: International Center for Transitional Justice.

Winter, S. (2014). Transitional Justice in Established Democracies: A Political Theory. New York: Palgrave Macmillan. 